\title{
The Effectiveness of Pentagon Fraud in Detecting Fraudulent Financial Reporting: Using the Beneish Model in Manufacturing Companies on the Indonesia Stock Exchange
}

\author{
Arief Himmawan Dwi Nugroho ${ }^{1}$ \\ Accounting Department, Economic \& Business \\ Faculty Stikubank University \\ Semarang, Indonesia \\ ariefhimmawan@edu.unisbank.ac.id
}

\author{
Alfasadun $^{2}$ \\ Accounting Department, Economic \& Business \\ Faculty Stikubank University \\ Semarang, Indonesia
}

\author{
Muhammad Ardinata ${ }^{3}$ \\ Accounting Department, Economic \& Business \\ Faculty Stikubank University \\ Semarang, Indonesia
}

\author{
Rofidah Yunita Ambarsari ${ }^{4}$ \\ Accounting Department, Economic \& Business \\ Faculty Stikubank University \\ Semarang, Indonesia
}

\begin{abstract}
This study aims to analyze the effect of pressure, opportunity, rationalization, capability, arrogance on fraudulent financial reporting. The population in this study are manufacturing companies listed on the Indonesia Stock Exchange.

The results showed that financial stability pressures, industrial conditions had a positive and significant effect on fraudulent financial reporting, while the change of directors had a significant negative effect on fraudulent financial reporting. Financial stability pressures will tend to create fraudulent financial reporting and the capability to change directors can prevent fraudulent financial reporting. Financial target pressures, external pressures, institutional ownership, effectiveness of supervision, industrial conditions, changes in auditors, total accruals and arrogance do not have a significant effect on fraudulent financial reporting.
\end{abstract}

Keywords : pressure, opportunity, rationalization, capability, arrogance, fraudulent financial reporting

\section{INTRODUCTION}

Financial reporting has benefits for most users in making economic decisions as well as management's accountability for the use of company resources. Financial reports should be able to present and disclose information that is relevant, honest and not fraudulent. Companies must know the internal and external factors that affect fraudulent financial reporting, fraudulent financial reporting is the financial condition of a company through deliberate misstatement or omission of amounts or disclosures in financial statements to deceive users of financial statements. Several factors can be used to detect or predict the existence of fraudulent financial reporting.

The principal's demands on management, in carrying out the company's activities, achieving the target desired by the principal can lead to acts of fraud. [1], [2], and [3] state that financial targets have a positive and significant effect on fraudulent financial reporting. In contrast to research [4], [5], [6], [7], [8], [9], [10], [11], [12], [13] and [14] stated that financial targets have no effect on fraudulent financial reporting.

Financial stability is a condition that describes whether the financial condition is in a stable condition. Financial stability can be reflected in financial information. This pressure on financial stability will lead to management actions to provide incorrect financial information. In research [4], [5], [2], [7], [6], [9 ], [15] and [3] state that financial stability targets have a positive and significant effect on fraudulent financial reporting while [1] and [8] state that financial stability has a negative and significant effect on fraudulent financial reporting. In contrast to research conducted by [6], [11], [10], [12], [13], [14] and [16] which state that financial stability has no effect on fraudulent financial reporting.

External pressure is a situation where the company gets pressure from outside the company. [4], [5], [2] and [13] state that external pressure has a positive and significant effect on fraudulent financial reporting while [1], [7], [3], [14] and [16] which state that external pressure has a negative and significant effect on fraudulent financial reporting. In contrast to research conducted by [6], [8], [10], [11] and [12] which states that external pressure has no effect on fraudulent financial reporting.

Institutional ownership becomes a company pressure because of greater responsibility to institutional shareholders and prevents loss of investors. [13] states that institutional ownership has a positive and significant effect on fraudulent financial reporting. In contrast to research conducted by [1], [5], [9], [3], [14], and [16] who state that institutional ownership has no effect on fraudulent financial reporting. 
The opportunity for fraud is due to the ineffective supervision of the board of commissioners. [2] state that the effectiveness of supervision has a positive and significant effect on fraudulent financial reporting, while [5], [10] and [13] state that effectiveness Supervision has a negative and significant effect on fraudulent financial reporting. In contrast to research conducted by [4], [1], [6], [8], [9], [11], [12] and which state that the effectiveness of supervision has no effect on fraudulent financial reporting.

The condition of the company can be seen from the assets that have the most material transactions. The occurrence of fraudulent acts can occur through manipulation of transactions in the company, for example manipulating the acknowledgment of trade receivables transactions so that the company's condition looks good. [4], [2], [8] and [3] stated that the company's condition had a positive and significant effect on fraudulent financial reporting, while [12] stated that it had a negative and significant effect on fraudulent financial reporting. In contrast to 2 research conducted by [1], [5], [7], [10], [11], [13] and [14] who state that the company's condition has no effect on fraudulent financial reporting.

It is a rational reason for the change of auditors so that the next audit results will be of higher quality and subsequently be able to detect fraud. [2], [11] and [15] state that auditor changes have a positive and significant effect on fraudulent financial reporting. In contrast to research conducted by [4], [5], [6], [8], [9], [3], [13], [14] and [16] which state that auditor change has no effect on fraudulent financial reporting.

The application of an accrual basis to recognize certainty in future events forms the basis for preparing financial statements. [4], and [10] state that total accruals have a positive and significant effect on fraudulent financial reporting. In contrast to research conducted by [6] and [17] which state that total accruals have no effect on fraudulent financial reporting.

There was fraud depending on the capacity of the Board of Directors in implementing each decision. The change of Directors is made in order to find people who are more competent and have integrity in running the company. [2] and [16] stated that the change of directors had a positive and significant effect on fraudulent financial reporting, while [15] stated that the change of directors had a negative and significant effect on fraudulent financial reporting. In contrast to research conducted by [4], [7], [8], [9], [10], [12] and [3] which state that the change of directors has no effect on fraudulent financial reporting.

The arrogance of a CEO can lead to the desire to always appear more in every company event. [6] state that the frequency of appearance of CEO images has a significant positive effect on fraudulent financial reporting, while [15] state that the frequency of appearance of CEO images has a significant negative effect on fraudulent financial reporting. In contrast to research conducted by [6], [8], and [16] which stated that the frequency of appearance of CEO images had no effect on fraudulent financial reporting.

The inconsistency of the research results means thatl the formulation of the research problem is what factors can affect fraudulent financial reporting.

\section{METHOD}

\section{Data Resources}

The type of data used in this study is secondary data. Secondary data used in this research is annual report data. The data used in this research are annual reports obtained from www.idx.co.id and the Indonesia Stock Exchange.

\section{Population and Sample}

The population in this study are manufacturing companies listed on the Indonesia Stock Exchange. Sample selection is determined based on certain characteristics. namely first, the company is listed on the Indonesia Stock Exchange during the period 2015 to 2017. Second, the company publishes an annual financial report which is stated in rupiah currency. Third, the completeness of the data required in the study.

\section{Definition of operational variables}

In this study, to measure fraudulent financial reporting using the Beneish M-Score Model [18]. This model uses a ratio scale and has limitations against which a company conducts fraudulent financial reporting. The Beneish model can be represented by the formula as follows:

$\mathrm{M}$-Score $=-4.84+0.920 \mathrm{DSRI}+0.528 \mathrm{GMI}+0.404 \mathrm{AQI}+$ $0.892 \mathrm{SGI}+0.11 \mathrm{DEPI}-0.172 \mathrm{SGAI}+4.679 \mathrm{TATA}-$ $0.327 \mathrm{LEVI}+\mathrm{e}$

Description of the Beneish Model :

Days Sales in Receivables Index $($ DSRI $)=($ Net Receivables $t /$ Sales $\left.{ }_{t}\right) /\left(\right.$ Net Receivales $_{t-1} /$ Sales $\left._{t-1}\right)$

Gross Margin Index $($ GMI $)=\left[\left(\right.\right.$ Sales $_{t-1}-$ Cost of Good Sold $t-$ 1)/Sales $\left.t_{t-1}\right] /\left[\left(\right.\right.$ Sales $_{t}-$ Cost Of Good Sold $\left.t\right) /$ Sales $\left._{t}\right)$

Aset Quality Index $(\mathrm{SGI})=1-\left[\left(\right.\right.$ Current Aset $\left._{\mathrm{t}}+\mathrm{PPE}_{\mathrm{t}}\right) /$ Total Aset t]/ 1-[(Current Aset $\left.{ }_{\mathrm{t}-1}+\mathrm{PPE}_{\mathrm{t}-1}\right) /$ Total Aset $\left._{\mathrm{t}-1}\right]$

Sales Growth Index (SGI) $=$ Sales $t /$ Sales $t-1$

Depreciation Index $(\mathrm{DEPI})=\left[\right.$ Depreciation ${ }_{\mathrm{t}-1} /\left(\mathrm{PPE}_{\mathrm{t}-1}+\right.$ Depreciation $\left.\left._{t-1}\right)\right] /\left[\right.$ Depreciation $_{t} /\left(\mathrm{PPE}_{\mathrm{t}}+\right.$ Depreciation $\left.\left._{\mathrm{t}}\right)\right]$

Sales General and Administrative Expenses Index (SGAI) = (SG\&A Expense $t /$ Sales $\left._{\mathrm{t}}\right) /\left(\mathrm{SG}_{\mathrm{S}}\right.$ A Expense $_{\mathrm{t}-1} /$ Sales $\left._{\mathrm{t}-1}\right)$

Leverage Index $($ LVGI $)=[($ Current Liabilities $t+$ Long Term Debt ${ }_{\mathrm{t}}$ / $/$ Total Aset $] /$ [(Current Liabilities $\mathrm{t}-1+$ Long Term Debt $\mathrm{t}$ 1)/TA)

Total Accruals to Total Assets $($ TATA $)=($ Current Assets - Cash - Current Liabilities - Current Maturities of LTD - Income Tax Payable - Depreciation and Amortization)/Total Aset $\mathrm{t}$

If the M-Score result is more than -2.22 , it is categorized as a company that has committed fraud. Meanwhile, if the score is less than -2.22, it is categorized as a company that has not committed fraud (non-fraud). Companies that commit fraud are given a score of 1 and those that have not committed fraud are given a score of 0 .

Measurement of Independent Variables:

Financial targets $=$ Retum $/$ Aset

2. Financial stability $=($ Total Aset $t-$ Total Aset $t-1) /$ Total $t-1$

3. External pressure $=$ Total Liability $/$ Total Aset

4. Institutional ownership $=$ Shares owned by institusional / 
Common shares outstanding

5. Board of commissioners $=$ the number of independent commissioners / number of board commissioners

6. Industrial conditions $=($ Receivables $t /$ Sales $t)-($ Receivables $\mathrm{t}-1 /$ Sales $\mathrm{t}-1$ )

7. Change in auditors $=$ If there is a change in auditor, code 1 is given, otherwise if there is no change, it is coded 0 .

8. Total Accruals = Total accruals divided by total assets, where total accruals are calculated as the change in current assets, minus the change in cash, minus changes in current liabilities, plus the change in short-term debt, minus depreciation and amortization expense, minus deferred tax on earnings, plus equity in earnings

9. Change of Directors $=$ If there is a change in Director, code 1 is given, otherwise if there is no change, it is coded 0 .

10. CEO Picture $=$ The number of CEO images

\section{RESULT AND DISCUSSION}

The population in this study are manufacturing companies listed on the Indonesia Stock Exchange. The samples that met the criteria were 111 manufacturing companies. The research observation period is 2015 to 2017 .

\subsection{Goodness of fit test}

TABLE 1 Results of the Hosmer and Lemeshow's Test

\begin{tabular}{|r|r|r|r|}
\hline$p$ & $\begin{array}{c}\text { Chi- } \\
\text { square }\end{array}$ & Df & \\
\hline & 3,573 & 8 &, 893 \\
\hline
\end{tabular}

Resources : the results of data processing

Based on table 1 shows chi-square $=3.573$ with $\mathrm{a}$ significance of 0.893 . With this a significance value greater than 0.05 means that the model is able to predict the observation value or the model can be accepted according to the observation data.

TABEL 2 Result Likelihood Overall Test

Block 0

\begin{tabular}{|l|r|l|}
\hline \multirow{2}{*}{ Iteration } & & \multicolumn{1}{l|}{ Coefficients } \\
\cline { 3 - 3 } & -2 Log likelihood & Constant \\
\hline 0 & 418,235 &,- 715 \\
418,156 &,- 748 \\
& 418,156 &,- 748 \\
\hline
\end{tabular}

Block 1

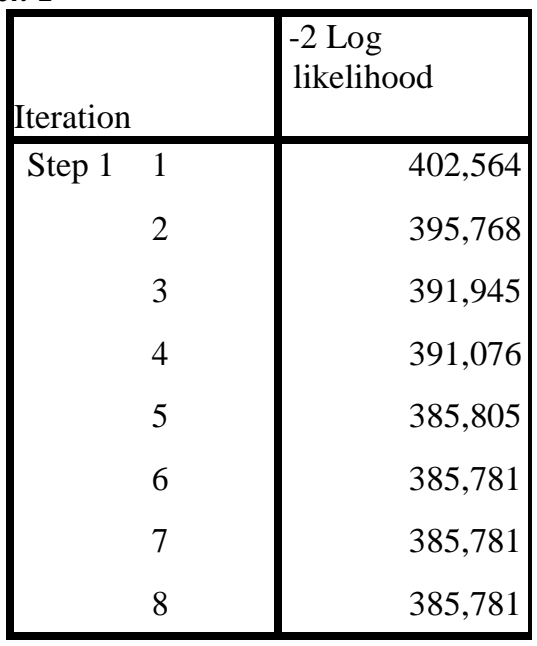

Resources : the results of data processing

Block number 0 shows a -2 log likelihood value of 418.156 while block number 1 shows a $-2 \log$ likelihood value of 385,781 . From the two blocks, it can be seen that there is a decrease in the value of $-2 \log$ likelihood. This decrease in the value of $-2 \log$ likelihood indicates a good regression model. The decrease in the value of $-2 \log$ likelihood is presented in the value of the omnibus test of model coefficients.

TABEL 3 Result Omnibus Test of Model Coefficients

\begin{tabular}{|ll|c|c|c|}
\hline & & Chi-square & \multicolumn{1}{|l|}{ Df } & \\
\hline Step & Step & 32,375 & 10 &, 000 \\
& Block & 32,375 & 10 &, 000 \\
& Model & 32,375 & 10 &, 000 \\
\hline
\end{tabular}

Resources : the results of data processing

Omnibus test of model coefficients, chi square value of 32.375 with a significance value of 0.000 , meaning that there is a significant effect of the independent variable on the dependent variable.

TABEL 4 Result Cox and Snell's R Square dan Nagelkerke's R Square

\begin{tabular}{|r|r|r|l|}
\hline Step & $\begin{array}{c}\text { Cox \& Snell R } \\
-2 \text { Log } \\
\text { likelihood }\end{array}$ & Square & Nagelkerke R \\
\hline & $385,781^{a}$ &, 093 &, 130 \\
\hline
\end{tabular}

Resources : the results of data processing

Based on the test results, this research model can be explained by the independent variable by $13 \%$ while the remaining $87 \%$ is explained by other variables outside the model. 
TABLE 5 Regression Test Result

\begin{tabular}{|l|r|r|}
\hline \multicolumn{1}{|c|}{ Variables } & B & Sig. \\
\hline ROA &, 019 &, 984 \\
ACHANGE & 1,529 &, 014 \\
LEV &, 152 &, 682 \\
OSHIP &,- 005 &, 994 \\
BDOUT &,- 300 &, 763 \\
RECEIVABLE & 3,678 &, 014 \\
AUDCHANGE &,- 340 &, 280 \\
TATA &, 748 &, 127 \\
DCHANGE &,- 608 &, 029 \\
CEOPIC &, 000 &, 995 \\
Constant & $-1,001$ &, 208 \\
\hline
\end{tabular}

3.2. Hypotheses testing

1. The Effect of Financial Targets on Fraudulent Financial Reporting (H1)

2. The financial target has a standard coefficient of $\beta=0.019$ with a significance value of $0.984>0.05$. This means that financial targets have no effect on fraudulent financial reporting. In this case, it can be interpreted that $\mathrm{H} 1$ which states that financial targets have a positive and significant effect on fraudulent financial reporting is rejected.

3. The Effect of Financial Stability on Fraudulent Financial Reporting (H2).

Financial stability has a standard coefficient of $\beta=1.529$ with a significance value of $0.014<0.05$. This means that financial stability has an effect on fraudulent financial reporting. In this case it can be interpreted that $\mathrm{H} 2$ which states that financial stability has a positive and significant effect on fraudulent financial reporting received.

4. The Effect of External Pressure on Fraudulent Financial Reporting (H3)

External pressure has a standard coefficient $\beta=0.152$ with a significance value of $0.682>0.05$. This means that external pressure has no effect on fraudulent financial reporting. In this case it can be interpreted that $\mathrm{H} 2$ which states that external pressure has a negative and significant effect on fraudulent financial reporting is rejected.'

5. The Effect of Institutional Ownership on Fraudulent Financial Reporting (H4)

Institutional ownership has a standard coefficient of $\beta=$ 0.005 with a significance value of $0.994>0.05$. This means that institutional ownership has no effect on fraudulent financial reporting. In this case, it can be interpreted that $\mathrm{H} 4$ which states that institutional ownership has a positive and significant effect on fraudulent financial reporting is rejected.

6. The Effect of the Board of Commissioners on Fraudulent Financial Reporting (H5)

The independent board of commissioners has a standard coefficient of $\beta=0.748$ with a significance value of $0.763>$ 0.05 . This means that the independent board of commissioners has no effect on fraudulent financial reporting. In this case, it can be interpreted that H5 which states that the Board of Commissioners has a negative and significant impact on fraudulent financial reporting is rejected.

7. The Influence of Industry Conditions on Fraudulent Financial Reporting (H6)

Industrial conditions have a standard coefficient $\beta=3.678$ with a significance value of $0.014<0.05$. This means that industry conditions have an effect on fraudulent financial reporting. In this case, it can be interpreted that $\mathrm{H} 6$ states that industrial conditions have a positive and significant effect on fraudulent financial reporting received.

8. The Effect of Auditor Changes on Fraudulent Financial Reporting (H7)

Auditor change has a standard coefficient $\beta=-0.340$ with a significance value of $0.280>0.05$. This means that auditor changes have no effect on fraudulent financial reporting. In this case it can be interpreted that $\mathrm{H} 7$ which states that auditor changes have a negative and significant effect on fraudulent financial reporting is rejected.

9. The Effect of Total Accruals on Fraudulent Financial Reporting (H8)

Total accruals have a standard coefficient $\beta=-0.340$ with a significance value of $0.127>0.05$. This means that total accruals have no effect on fraudulent financial reporting. In this case it can be interpreted that $\mathrm{H} 8$ which states that total accruals have a positive and significant effect on fraudulent financial reporting is rejected.

10. The Effect of Change of Directors on Fraudulent Financial Reporting (H9)

The change of directors has a standard coefficient of $\beta=$ 0.608 with a significance value of $0.029<0.05$. This means that the change of directors has an effect on fraudulent financial reporting. In this case, it can be interpreted that $\mathrm{H} 9$ states that the change of directors has a negative and significant effect on fraudulent financial reporting received.

11. Effect of CEO image on Fraudulent Financial Reporting (H10).

The number of published CEO images has a standard coefficient of $\beta=0.000$ with a significance value of $0.995>$ 0.05 . This means that the appearance of the CEO image has no effect on fraudulent financial reporting. In this case, it can be interpreted that $\mathrm{H} 10$ which states that the appearance of the CEO image has a positive and significant effect on fraudulent financial reporting is rejected.

Discussion

1. The Effect of Financial Targets on Fraudulent Financial Reporting (H1)

The test results show that financial targets have no effect on fraudulent financial reporting. The company is able to achieve profitability growth due to the ability and competence of management in managing assets. The profitability achieved by management is not due to overstatement of assets and income. The results of this study support previous research conducted by [5], [6], [7], 
[8], [9], [10] and [13].

2. The Effect of Financial Stability on Fraudulent Financial Reporting (H2).

Financial stability is threatened by certain circumstances will affect asset growth. Management who is under pressure to continue to show that the company is still able to manage assets well under these conditions. Improved asset management aims to get a good assessment which will have an impact on giving bonuses to management. The results of this study support previous research conducted by [4], [5], [2], [7], [9], [15], [19] and [3].

3. The Effect of External Pressure on Fraudulent Financial Reporting (H3)

External pressure from creditors is not always a major consideration for management in seeking funding from other creditors. Companies that have large debts do not necessarily commit fraud. The high leverage of a company is the creditor's level of trust in management. The results of this study support previous research conducted by [8], [10], [12] and [19].

4. The Effect of Institutional Ownership on Fraudulent Financial Reporting (H4)

Institutional share ownership does not affect fraudulent financial reporting. Institutional interest is more possible because it aims to control other companies. In addition, it is more concerned with getting dividends and stock returns. The results of this study support previous research conducted by [1], [5] and [16].

5. The Effect of the Board of Commissioners on Fraudulent Financial Reporting (H5)

Independent commissioners have not had an effect on fraudulent financial reporting. Independent commissioners are only limited as a regulatory requirement in fulfilling good corporate governance. Commissioners are not required to have special competencies that are able to prevent fraudulent financial reporting. The results of this study support previous research conducted by [8], [9], [19] and [14].

6. The Influence of Industry Conditions on Fraudulent Financial Reporting (H6)

Industry conditions can be seen in the asset account with overstatement risk. Accounts receivable transactions have a high risk of not conforming to separate limits, fictitious receivables and the recognition of impairment losses that are not in accordance with the conditions. This can indicate fraudulent financial reporting. The results of this study support previous research conducted by [4], [2], [8] and [3].

7. The Effect of Auditor Changes on Fraudulent Financial Reporting (H7)

External auditors in conducting financial audits are one of the prevention and detection of fraudulent financial reporting. Every auditor in conducting an audit must be based on auditing standards whether public accountants are affiliated with the Big Four or not. So that the replacement of auditors is not intended to enable the replacement auditors to find Financial Reporting. The results of this study support previous research conducted by [4], [5], [8], [9], [19], [3], [13], [14] and [16].

8. The Effect of Total Accruals on Fraudulent Financial Reporting (H8)

Recording accrual transactions is caused to meet accounting standards, not as a means of fraudulent financial reporting. In preparing financial statements, accrual assumptions must be used. The results of this study support previous research conducted by [6] and [17].

9. The Effect of Change of Directors on Fraudulent Financial Reporting (H9)

The change of directors is not only aimed at improving company performance. With the replacement of directors who are more competent and have integrity, it can prevent fraudulent financial reporting. The results of this study support previous research conducted by [15].

10. Effect of CEO image on Fraudulent Financial Reporting (H10).

The number of CEO images published does not indicate CEO arrogance which has an impact on fraudulent financial reporting. The CEO appearing in public is a representation of the company's presence at ceremonial events. The results of this study support previous research conducted by [8], [19] and [16].

\section{CONCLUSION}

1. Financial targets have no effect on fraudulent financial reporting.

2. Financial stability has a positive and significant effect on fraudulent financial reporting.

3. External pressure has no effect on fraudulent financial reporting.

4. Institutional ownership has no effect on fraudulent financial reporting.

5. The effectiveness of supervision does not affect fraudulent financial reporting.

6. Industry conditions have a positive and significant effect on fraudulent financial reporting.

7. Changes in auditors do not affect fraudulent financial reporting.

8. Total accruals have no effect on fraudulent financial reporting.

9. Changes of directors have a negative and significant effect on fraudulent financial reporting.

10. CEO image frequency has no effect on fraudulent financial reporting.

Research Limitations

This research model is only able to explain the effect of independent variables on fraudulent financial reporting by $13 \%$. This shows that there are other variables that can affect Fraudulent Financial Reporting. 


\section{REFERENCES}

[1] Widarti. 2015. Pengaruh Fraud Triangle Terhadap Deteksi Kecurangan Laporan Keuangan Pada Perusahaan Manufaktur Yang Terdaftar Di Bursa Efek Indonesia (BEI). Jurnal Manajemen dan Bisnis Sriwijaya Vol. 13 No. 2.

[2] Putriasih, Ketut, Ni Nyoman Trisna Herawati dan Made Arie Wahyuni. 2016. Analisis Fraud Diamond Dalam Mendeteksi Financial Statement Fraud: Studi Empiris Pada Perusahaan Manufaktur Yang Terdaftar Di Bursa Efek Indonesia (BEI) Tahun 2013-2015. e-Journal S1 Ak Universitas Pendidikan Ganesha Jurusan Akuntansi Program S1 Vol. 6 No. 3.

[3] Warsidi, Bambang Agus Pramuka dan Suhartinah. 2018. Determinant Financial Statement Fraud: Perspective Theory Of Fraud Diamond (Studi Empiris pada Perusahaan Sektor Perbankan di Indonesia Tahun 2011-2015). Jurnal Ekonomi, Bisnis, dan Akuntansi (JEBA) Vol. 20 No. 3.

[4] Sihombing, Kennedy Samuel dan Shiddiq Nur Rahardjo. 2014. Analisis Fraud Diamond Dalam Mendeteksi Financial Statement Fraud: Studi Empiris Pada Perusahaan Manufaktur Yang Terdaftar Di Bursa Efek Indonesia (BEI) Tahun 2010-2012. Diponegoro Journal Of Accounting Vol. 03 No. 02 Hal. 1-12.

[5] Tiffani, Laila dan Marfuah. 2015. Deteksi Financial Statement Fraud Dengan Analisis Fraud Triangle Pada Perusahaan Manufaktur Yang Terdaftar Di Bursa Efek Indonesia. Jurnal Akuntansi Dan Auditing Indonesia Vol. 19 No. 2 Hal. 112- 125.

[6] Aprillia, Orlin Cicilia dan Rafaela Pertiwi Sergius. 2015. The Effectiveness Of Fraud Triangle On Detecting Fraudulent Financial Statement: Using Beneish Model And The Case Of Special Companies. Jurnal Riset Akuntansi dan Keuangan Vol. 3 No. 3 Hal. 786-800

[7] Annisya, Mafiana, Lindrianasari dan Yuztitya Asmaranti. 2016. Pendeteksian Kecurangan Laporan Keuangan Menggunakan Fraud Diamond. Jurnal Bisnis dan Ekonomi (JBE) Vol. 23 No. 01 Hal. 72-89.

[8] Kurnia, Aidil Adherian dan Idrianita Anis. 2017. Analisis Fraud Pentagon Dalam Mendeteksi Kecurangan Laporan Keuangan Dengan Menggunakan Fraud Score Model. Simposium Nasional Akuntansi XX.

[9] Apriliana, Siska dan Linda Agustina. 2017. The Analysis of Fraudulent Financial Reporting Determinant through Fraud Pentagon Approach. Jurnal Dinamika Akuntansi Vol. 9 No. 2 Hal. 154-165.

[10] Oktarigusta, Lutfiana. 2017. Analisis Fraud Diamond Untuk Mendeteksi Terjadinya Financial Statement Fraud Di Perusahaan (Studi Empiris Pada Perusahaan Manufaktur Yang Terdaftar Di BEI Tahun 2012-2015). Jurnal Ekonomi Manajemen Sumber Daya Vol. 19 No. 2 Hal. 93-108.

[11] Wahyuni dan Gideon Setyo Budiwitjaksono. 2017. Fraud Triangle Sebagai Pendeteksi Kecurangan Laporan Keuangan. Jurnal Akuntansi Vol. 21 No. 01 Hal. 47-61.

[12] Indriani, Poppy dan M. Titan Terzaghi. 2017. Fraud Diamond Dalam Mendeteksi Kecurangan Laporan Keuangan. I-Finance Vol. 3 No. 2.

[13] Utomo, Langgeng Prayitno. 2018. Kecurangan Dalam Laporan Keuangan Menguji Teori Fraud Triangle. Jurnal Akuntansi dan Pajak Vol. 19 No. 01 Hal.77-88.

[14] Zahro, Yulia, Nur Diana dan M. Cholid Mawardi. 2018. Deteksi Financial Statement Fraud Dengan Analisis Fraud Triangle Pada Perusahaan Manufaktur Yang Terdaftar Di BEI. E-JRA Vol. 07 No. 09.

[15] Siddiq, Faiz Rahman, Fatchan Achyani dan Zulfikar. 2017. Fraud Pentagon Dalam Mendeteksi Financial Statement Fraud. Seminar Nasional dan The 4th Callfor Syariah Paper.

[16] Bayagub, Amira, Khusnatul Zulfa dan Ardyan Firdausi Mustoffa. 2018. Analisis Elemen-Elemen Fraud Pentagon Sebagai Determinan Fraudulent Financial Reporting (Studi Pada Perusahaan Property dan Real Estate Yang Terdaftar Di Bursa Efek Indonesia Periode 2014-2016). Jurnal Ekonomi, Manajemen dan Akuntansi Vol. 2 No. 1 Hal. 1-11.

[17] Tarjo dan Nurul Herawati. 2015. Application of Beneish M-Score Models and Data Mining to Detect Financial Fraud. Procedia -
Social and Behavioral Sciences 211 Hal. 924-930.

[18] Beneish, Messod D. 1999. The Detection of Earnings Manipulation. Financial Analysts Journal Vol. 55 No. 5. Hal. 24-36.

[19] Aprilia. 2017. Analisis Pengaruh Fraud Pentagon Terhadap Kecurangan Laporan Keuangan Menggunakan Beneish Model Pada Perusahaan Yang Menerapkan Asean Corporate Governance Scorecard. Jurnal Aset (Akuntansi Riset) Vol. 9 No. 1 Hal. 101 132 . 